\title{
THE EDUCATION PROCESS IMPLEMENTATION \\ OF THE CHILD WITH SPECIAL EDUCATIONAL NEEDS \\ IN THE INCLUSIVE SCHOOL ENVIRONMENT
}

\author{
Kokkali Danai \\ Postgraduate Student at the Department of English Philology and Methodics of English Learning \\ Ternopil Volodymyr Hnatiuk National Pedagogical University \\ M. Kryvonosa str., 2, Ternopil, Ukraine \\ orcid.org/0000-0003-1478-3088 \\ danaidona2@gmail.com
}

Sokol M. O.

Doctor of Pedagogical Sciences,

Professor at the Department of Romanic-German Philology

Ternopil Volodymyr Hnatiuk National Pedagogical University

M. Kryvonosa str., 2, Ternopil, Ukraine

orcid.org/0000-0003-3876-026X

maryanasokol@ukr.net

Key words:

inclusion, special needs, pedagogical aspect, education.
The education process implementation of the child with special educational needs in the inclusive school environment has been outlined in the article. The inclusion-historical background of special education effectiveness has been described. The research background of inclusion legislation in Greece has been analyzed. As a result it has been stated that almost all children, regardless of the type of difficulties they face, can and must attend general school, supported by the appropriate special education structure depending on their case and to this law. Students with special educational needs of primary education can study as stated in their clinical profile: in the general classroom, in the general classroom supported by a parallel support teacher, in the integration department that operates within the general school, in a special kindergarten or primary school, in branches of schools located in hospitals, rehabilitation centers, etc. or with home-teaching. The evaluation process of special educational needs of school age children has been studied. The effectiveness of the working process of The Center for Differential Diagnosis, Diagnosis and Support (KEDDY) has been learned. It has been shown that the interdisciplinary committee of KEDDY does the evaluation of each child. This committee consists of a special pedagogue of the school level to which the child belongs, a doctor, a social worker, a speech therapist and a psychologist. The detailed analyses of the clinical profile that contains all the characteristics of the child, his weaknesses, his strengths and the differences has been shown. The personalized intervention program based on the proposal mentioned in the evaluation report that describes the clinical profile of the student with special educational needs has been analyzed. The role of the teacher as key parameter that determines the content of special education has been discovered. The philosophic aspect of inclusive education changes the teacher's role: who must now be aware of the special characteristics of children with special educational needs, who notice a problem and as a result, their attitude and ability can influence parents or the school to seek professional help has been outlined in the article. 


\title{
ІМПЛЕМЕНТАЦІЯ НАВЧАЛЬНОГО ПРОЦЕСУ В ДІТЕЙ $З$ ОСОБЛИВИМИ ПОТРЕБАМИ В ІНКЛЮЗИВНОМУ ОСВІТНЬОМУ СЕРЕДОВИЩІ
}

\author{
Коккалі Данаі \\ аспірантка кафедри англійської філології та методики навчання англійської мови \\ Тернопільський національний педагогічний університет імені Володимира Гнатюка \\ вул. М. Кривоноса, 2, Тернопіль, Україна \\ orcid.org/0000-0003-1478-3088 \\ Сокол М. О. \\ доктор педагогічних наук, \\ професор кафедри романо-германської філології \\ Тернопільський національний педагогічний університет імені Володимира Гнатюка \\ вул. М. Кривоноса, 2, Тернопіль, Україна \\ orcid.org/0000-0003-3876-026X \\ maryanasokol@ukr.net
}

\section{Ключові слова:}

інклюзія, особливі потреби, педагогічний аспект, освіта.
У статті проаналізовано імплементацію навчального процесу у дітей 3 особливими потребами в інклюзивному освітньому середовищі. Досліджено інклюзивно-історичні засади впровадження спеціальної освіти. Проаналізовано наукове підгрунтя інклюзивного законодавства у Греції. Спеціальна освіта є галуззю гуманітарних наук і незалежною наукою, яка зосереджена на систематичному вивченні та навчанні дітей з особливими освітніми потребами в загальному спектрі навчання та поведінки. Як наслідок, доведено, що майже усі діти, незважаючи на певні труднощі, що постають перед ними, можуть і мають відвідувати школу, окрім того, вони отримують належну підтримку від спеціальних підрозділів чи організацій. Учні з особливими освітніми потребами в початковій школі можуть навчатися відповідно до їхніх клінічних характеристик: у звичайному класі, звичайному класі з паралельним супроводом додаткового вчителя, в інтегрованому закладі, що належить до школи, у спеціальному дошкільному закладі, розташованому в лікарні, в реабілітаційному центрі чи домашньому навчанні тощо. Вивчено процес оцінювання дітей шкільного віку з особливими освітніми потребами. Вивчено ефективність робочого процесу Центру диференціальної діагностики, підтримки (KEDDY). Зазначено, що міждисциплінарна комісія KEDDY детально аналізує кожну дитину. Цей центр складається зі спеціального педагога шкільного рівня, до якого належить дитина, лікаря, соціального працівника, логопеда та психолога. Подано детальний аналіз клінічного профілю, який містить усі характеристики дитини, його слабкі сторони, сильні сторони та відмінності. Проаналізовано персоналізовану програму інтервенції навчання дітей з особливими освітніми потребами, що описує клінічний профіль учня та його готовність до шкільного середовища. У статті виокремлено філософський аспект інклюзивної освіти, що змінює роль вчителя, який усвідомлює особливості дітей з особливими освітніми потребами, звертає увагу на цю проблему і має змогу висловлювати власну точку зору щодо навчання таких дітей.
Problem statement. Special Education is a branch of the Humanities and is an independent science that focuses on the systematic study and treatment of children with special educational needs across the learning and behavioral spectrum. Special education as a scientific brunch is about a hundred years old, as it seems that its first steps began in the early 19th century. In Greece, it timidly emerged in 
the '50s and went through various development stations, which have been completely intertwined with the attitudes and perceptions of society in each era. These stations defined its content and purpose at different times [11, p. 23].

It should be stated that doctors have been the first to study cases of people with special educational needs and identify their characteristics. As a result, primary attempts to treat them have been made from a medical point of view. This means that they focused on what the individual cannot do, so he had to be healed in order to integrate smoothly into society [1, p. 201]. The medical model prevailed for several years and has been identified with the stage of compassion, care, protection and special education. This has been resulted in the creation of asylum and treatment facilities for these individuals [11, p. 121].

Since then, significant progress has been made in the field of special education. The principle of normalization and the assumption that all individuals can be trained using appropriate programs has been led to deinstitutionalization and the effort to integrate students with special educational needs into the general school. This effort paved the way for a multidimensional model, which, while not dismissing the medical nature of each problem, seeks to combat the discrimination that may exist. According to this model, which is known as the inclusion model, it is necessary to fully co-educate all children in general school so that they have the maximum possible development of their cognitive and social [1, p. 202]. This model is a challenge for the teacher as it should adapt its attitude towards students with special educational needs and at the same time apply small and smart changes in the curriculum and its implementation so that it can be adapted to its specifics and each student be able to respond to the maximum possible degree [11, p. 23].

The aim of the article is to analyze the education process implementation of the child with special educational needs in the inclusive school environment.

The main material of the article. The concept of inclusion emerged in the early 1990s as a new philosophy. A new movement emerged through the struggle and the demands of the organizations of the disabled. It was caused by the reason of they have been no longer looking for a cure but have been claimed benefits for their equal participation in society [8, p. 27]. In 1994, in the Spanish city of Salamanca, 300 delegates from ninety-two governments and twenty-five international organizations have been studied the declaration "Education for All". However, every child had the right to education and that the education system must be designed in such way to include educational programs that respect the particular characteristics, interests or needs of each child. Among other things, this declaration urged all governments to prioritize the improvement of their educational systems by creating and passing laws based on the principle of Inclusive Education [11, p. 23; 10, p. 18].

Therefore, the Salamanca Declaration paves the way for inclusive education. This implies equal access of all students to all activities of school life, acceptance of the diversity of each student, equal participation of all students in the learning process in order to better develop their academic and social skills and also eliminate discrimination and exclusion experienced by these individuals [1, p. 203].

Greece is also adapting to the demands of the times and accepts the principles of Salamanca, passed in 2000 the Law 2817 for the "Education of people with special educational needs" and in 2008 the Law 3699 "Special education and training of people with disabilities or special educational needs". The new 2008 law emphasizes the participation of all people with special educational needs in all school activities [11, p. 21].

Law 3699/2008 stipulates that almost all children, regardless of the type of difficulties they face, can and must attend general school, supported by the appropriate special education structure depending on their case. According to this law, students with special educational needs of primary education can study as stated in their clinical profile: in the general classroom, in the general classroom supported by a parallel support teacher, in the integration department that operates within the general school, in a special kindergarten or primary school, in branches of schools located in hospitals, rehabilitation centers, etc. or with home-teaching [8, p. 27].

The Center for Differential Diagnosis, Diagnosis and Support (KEDDY) is responsible for the classification of students with special educational needs in the appropriate school structure, the appropriate school unit as well as the personalized intervention program and any other adaptations or educational aids that will facilitate the specific student [7, p. 127; 11, p. 23].

The Ministry of Education, through this law and all the provisions it receives, tries to upgrade the quality of education, which should be in accordance with each student and his special educational needs. In order to achieve this, it is necessary, among other things, to write a detailed clinical profile after the differential diagnosis made in KEDDY and then the design and implementation of the appropriate individualized intervention program by the interdisciplinary team $[11$, p. 23$]$.

The Differential Diagnosis and Support Centers (KEDDY) belong to the Ministry of Education and operate at the headquarters of each prefecture. They can be referred for evaluation by children aged 5 to 22 years after the request of the guardian and the necessary actions of the class teacher, the school principal and the school counselor [3, p. 75]. 
The classroom teacher is the one who will notice and see that something different is happening in the way the particular child is learning. Within this way, he/she should start collecting several data from observations and make recordings that will confirm this suspicion [11, p. 23]. The teacher will then inform the school principal and a first intervention will be made. If there is no result, the general education school counselor should be informed and a short-term intervention program will be created. If the intervention program is not successful then the special education counselor is informed and he/she decides whether it is necessary to refer the child for evaluation to KEDDY. Parents should be aware of the whole process and the child's progress and they will be the ones to apply for evaluation [3, p. 73]. The interdisciplinary committee of KEDDY does the evaluation of each child.

This committee consists of a special pedagogue of the school level to which the child belongs, a doctor (child psychologist or pediatrician or neurologist with the appropriate specialization), a social worker, a speech therapist and a psychologist [11, p. 24].

During the evaluation, each of the experts of the interdisciplinary team examines the child using the appropriate psychometric tools and compiles an evaluation report in order to exclude low mental potential as a factor in the problem. The child's psychological state is also examined. At the same time, the social worker forms, with information collected from an interview with the parents, the social profile of the student that describes the family environment in which the student grows up. This process identifies all those psychological or social factors that contribute to the developmental process of the student [2, p. 135].

Finally, the interdisciplinary team of KEDDY writes an evaluation report, an opinion, which describes the clinical picture of the student with learning difficulties. At the end of the report, a proposal is presented, based on which an individualized program will be designed and must be implemented in order to effectively address the difficulties of the child [11, p. 22].

The clinical profile contains all the characteristics of the child, his weaknesses, his strengths and the differences he presents from the typical students of his age. The clinical profile of each student is described in the report drawn up after the differential diagnosis that is made by the interdisciplinary team of [11, p. 24].

The interdisciplinary team of KEDDY uses various techniques in order to form the clinical profile of each child with special educational needs. Among the tools available, are measurement scales, interviews, direct observation and various complementary methods such as noometric tests, adaptive behavior scales, etc. [11, p. 23].

However, the evaluation process has some drawbacks that can have a wrong effect on the clinical pro- file. This can happen because the child's examination and observation takes place outside the classroom, in a limited time and under clearly defined and controlled conditions. Also, the specific tests evaluate the child's performance at the specific time under specific conditions. These conditions are very different from what is common in an ordinary school classroom. Moreover, the child's behavior and reactions at the time of the examination cannot be described as spontaneous and may differ from those presented in the authentic environment in which the child lives, such as school or family environment [11, p. 24]. For this reason, it is necessary for the child to be evaluated by the class teacher $[9$, p. 70$]$.

Important information can be sought through an interview with the class teacher. In this interview, the main goal is to gather as much information as possible from the child's direct observation in the school environment. Such information is related to the learning difficulties faced by the child, the interaction with his/her classmates or other problems that occur in his/ her academic performance. The interview can also provide information that is not about the student but is related to people who are exposed to the child, such as parents, teachers or others that can provide support and guidance to the teacher [11, p. 23].

The personalized intervention program is based on the proposal mentioned in the evaluation report that describes the clinical profile of the student with special educational needs. The teacher or the special educator applies the individualized program in the school classroom in order to work in the best possible way with the difficulties of the specific child [11, p. 24].

The heterogeneity of children with learning difficulties requires that the intervention program is completely individualized for each student. It also cannot be considered as a tool that could be successfully applied to any student with a similar disorder. This is because each intervention program is adapted to the difficulties and strengths of each child that have arisen from the diagnosis and compose the clinical profile. For example, an intervention program for a child with dyslexia cannot work with the same success in another child with dyslexia because each child has different points in which he or she has difficulty and in which he or she can succeed [11, p. 23].

A key parameter that determines the content of special education is the person involved in teaching. One of those involved is the teacher who, with his/her training, can, among other things, achieve an early detection of the difficulties that a student presents $[11$, p. 23]. Teachers' knowledge is a very important element in order to succeed the idea of inclusion. Because knowledge is one of the three dimensions that shape a person's attitude towards people with special educational needs and the idea of inclusion. 
It should be mentioned that attitude is the way each person moves and reacts to his social environment. The attitudes of teachers directly affect the inclusive process since they are relevant to the assessment, evaluation and way of teaching children with special educational needs [5, p. 301].

The philosophy of inclusive education changes the role of the teacher who must now be aware of the special characteristics of children with special educational needs [7, p. 125].

Teachers are the first who notice a problem and as a result, their attitude and ability can influence parents or the school to seek professional help [11, p. 87]. According to research that studies teachers' knowledge of ADHD, there seems to be a lack of information about this disorder, which may limit their ability to observe and identify a student with this disorder in their classroom. The same research reveals a lack of knowledge on issues of diagnosis of the disorder, which raises questions about the diagnosis process and the quality of their cooperation with the respective bodies [6, p. 471].

However, the role of the teacher does not stop at the early identification and the correct observation of the student with learning difficulties. This is the first stage because the teacher is also responsible for the final stage of implementation of the personalized program proposed by the interdisciplinary team of KEDDY [11, p. 23].

Conclusions. From the above mentioned it can be concluded that the teacher's knowledge and consequently his attitude affects the whole process of inclusion from the identification and the initiative of informing and referring the student for examination, to the teaching and the final implementation of the individualized program in the classroom.

The classroom teacher should initially have a positive attitude towards the idea of inclusion and students with special educational needs. It is important to know that there will be a student in a class belonging to one of the categories of special education. The teacher should then have the appropriate knowledge to identify the characteristics that differ from the characteristics of age and the sensitivity to differentiate his/her teaching and apply small tricks that can benefit this particular student.

All the information that the teacher will gather from observations as well as any attempt to intervene should be mentioned in the interview or in the descriptive evaluation report requested by KEDDY. It is obvious that the more detailed this information is, the more helpful it will be in the work of the interdisciplinary team as they will give a clear picture of how the child works in his natural space. The more comprehensive and complete the clinical profile of each student with special educational needs is, the better the personalized intervention program will be. Therefore, the intervention is more effective.

In conclusion, the training of teachers in special education and the principles of inclusive education is necessary for this new form of education, in order to achieve the best educational results not only for the students with special educational needs, but also for the whole student population.

\section{References}

1. Berberidis P. (2016) A school without restrictions. The model of full inclusion as a means of social inclusion in primary education. London: Maxwel, pp. 201-205.

2. Kaukoula E. (2010) Psychopedagogical Treatment of Learning Disabilities At the Education Department. 5th Panhellenic Conference on "Learning how to learn". Athens: PTU, pp. 131-135.

3. KEDDY Achaia (2015) Reference Procedure - Evaluation at KEDDY Achaia. EU: Bright, Pp. 71-78.

4. Kokkinos C.M., Panayiotou G., Davazoglou A. M. (2005) Corelates of teachers appraisals of student attitudes. Psychology in the Schools. New York: Beta press 42 (I), pp. 79-89.

5. Kountouriotou P., Dimakopoulou M. (2014) Attitudes of primary school teachers towards the pedagogy of co-education. Research study. New Teacher. New York: CcoC, pp. 116-314.

6. Kourantzi E. (2011) The knowledge of primary school teachers for Attention Deficit Hyperactivity Disorder (ADHD). International Conference: "Research Educational Policy \& Educational Practice in Special Education". Mytilene: University of the Aegean, pp. 463-476.

7. Kourkoutas E., Stavrou P.-D., Loizidou N. (2017) Exploring Teachers' Views on Including Children with Special Educational Needs in Greece: Implication for Inclusive Counseling. American Journal of Educational Research, vol. 5, Boston: Selta, pp. 124-130.

8. Lambropoulou V., Panteliadou S. (2015) Special Education in Greece - Critical Theory. Athens: I. Sideris Publications, pp. 25-27.

9. Polychronopoulou Z. (2001) Children and Adolescents with Special Needs and Possibilities (Vol. II). Private Publications. Athens: Star Co, pp. 49-70.

10. Salamanca (1994) Declaration of Salamanca and framework of action for the education of people with special needs. World Conference on the Education of Persons with Disabilities. Salamanca, pp. 17-20.

11. Stasinos D.P. (2013) Special Education 2020 Plus. Athens: Papazisis Publications, pp. 21-24. 